\title{
Performance evaluation of a cell in belt type metering device for planting of gladiolus corms
}

\section{PADAM SINGH AND TRIVENI PRASAD SINGH}

See end of the Paper for authors' affiliation

Correspondence to :

\section{PADAM SINGH}

Department of Farm Machinery and Power Engineering, College of Technology, Govind Ballabh Pant University of Agriculture and Technology, Pantnagar, U.S. NAGAR (UTTARAKHAND) INDIA

Email : padamsingh1990@ gmail.com
- ABSTRACT : Planting of gladiolus is traditionally performed by manual labour which is very arduous. Till date no planter has been developed for mechanizing this permeation. With this aim, a prototype gladiolus planter was developed with cell in belt types metering unit, the performance of the metering unit was evaluated in -situ condition with three; levels of forward speed $(1,1.5$ and $2 \mathrm{~km} / \mathrm{h}$ ) and three levels of nominal corm spacing $(15,20$ and $25 \mathrm{~cm})$. The test result indicated that the metering unit was able to deliver the some at sensors spacing but with an overall deviation of 15.08 per cent. The co-efficient of uniformity was found higher for $2 \mathrm{~km} / \mathrm{h}$ speed and $25 \mathrm{~cm}$ corm to deviation of 15.8 per cent. The co-efficient of uniformity was of und higher for $2 \mathrm{~km} / \mathrm{h}$ speed and 25 $\mathrm{cm}$ corm to corm spacing, the miss index was found less for wider spacing and higher speed of operation. Similarly, the quality feed index was found higher for wider nominal spacing and higher for wider nominal spacing and higher forward speed, however, the multiple index was found zero for all the treatment combinations. The overall performance was found better for $2 \mathrm{~km} / \mathrm{h}$ forward speed.

- KEY WORDS : Design parameter, Gladiolus planting, Physical properties, Performance evaluation, Planting mechanism

- HOW TO CITE THIS PAPER : Singh, Padam and Singh, Triveni Prasad (2017). Performance evaluation of a cell in belt type metering device for planting of gladiolus corms. Internat. J. Agric. Engg., 10(1) : 159-167, DOI: 10.15740/HAS/IJAE/10.1/159-167. 